\title{
AMS dating and ancient DNA analysis of bone relics associated with St John the Baptist from Sveti Ivan (Sozopol, Bulgaria)
}

\author{
R. Kostova ${ }^{\text {a }}$, K. Popkonstantinov ${ }^{\text {a }}$, H. Schroeder ${ }^{\text {b }}$, E. Willerslev ${ }^{\text {b }}$, A. Sultanov ${ }^{\text {c }}$, G. Kazan ${ }^{\text {d }}$, T. Higham ${ }^{\text {e }}$ \\ a Department of Archaeology, Faculty of History, St Cyril and St Methodius University of Veliko Tarnovo, Veliko Tarnovo, Bulgaria \\ ${ }^{\mathrm{b}}$ Centre for GeoGenetics, University of Copenhagen, Øster Voldgade 5-7, 1350 Copenhagen, Denmark \\ " University of Mining and Geology "St. Ivan Rilski”, 1700 Sofia, Bulgaria \\ d Turku Institute of Advanced Studies (Department of Archaeology), University of Turku, Arkeologia, 20014 Turun Yliopisto, Finland \\ e Oxford Radiocarbon Accelerator Unit, Research Laboratory for Archaeology and the History of Art, University of Oxford, Oxford OX1 3QY, England
}

\section{A R T I C LE INFO}

Keywords

AMS radiocarbon dating

Ancient DNA

Church archaeology

Early Christianity

Relics

\begin{abstract}
A B S T R A C T
Excavations in 2010 on the Black Sea island of Sveti Ivan (Bulgaria) revealed the remains of a miniature marble sarcophagus containing human and animal remains, along with an inscribed tufa ossuary, beneath a 4th to 5th-century church floor. We found that the tufa ossuary had strong links with Cappadocian rhyolite tuff. The inscriptions on its surface suggest links to John the Baptist since they refer to him by name and contain a reference to his nativity date of June 24. The ancient Greek text also mentions him in the genitive case, i.e. 'of Saint John'. Here, we review the historical evidence pertaining to the relics and conclude that they most likely reached Sveti Ivan via Constantinople during the 4-5th century CE. To shed more light on the relics, we sampled three of the remains for radiocarbon dating and ancient DNA analysis. Radiocarbon dating of one of the bones (a metacarpal) yielded a first century $\mathrm{AD}$ date (5-75 cal AD, 68.2\% probability). Ancient DNA analysis of this bone, as well as a rib fragment and a tooth, using shotgun sequencing yielded very little human DNA, ranging between 0 and $0.9 \%$ of sequenced reads. However, the DNA did not show any of the post-mortem damage patterns that are typical for ancient DNA. We conclude that the sequences we obtained are most likely the result of modern contamination.
\end{abstract}

\section{Introduction}

Relics are objects that survive from ancient times, often associated with a deceased holy person's body or their belongings, and kept as objects of reverence or worship. Relics have played a central role in the principal cultures and religions of the world (Judaism, Christianity, Islam, Hinduism and Buddhism). Early Christian relics derive predominantly from ecclesiastical collections, but in this paper, we describe a reliquary excavated from beneath a 4-5th century CE church altar in controlled conditions in Bulgaria, which revealed human and animal remains. There are strong arguments that link John the Baptist to the find through an inscription. We explore aspects of the find using archaeological science methods.

\section{The site and its archaeology}

Excavations on the island of Sveti Ivan (broadly translated as the Island of St John), near Sozopol in Bulgaria, were undertaken in 2010 in a church within part of a wider series of monastic buildings. The monastery is named St John the Forerunner (Prodromos), after the saint known in the West as St John the Baptist, and is situated in the southern part of the island. Sozopol was called Apollonia in ancient times and during the medieval period, Sozopolis (Soustal, 1991) (Fig. 1). The monastic complex covered an area of 0.5 ha on a terrace opened to the bay of Sozopol (Fig. 2). Archaeological excavations between 1985 and 1994 have established that the earliest church built there was a tri-aisle basilica with a single-apse sanctuary built in opus latericum and opus incertum (Fig. 2A). The aisles were divided by means of brick pillars (Di- mova et al., 1990). The basilica was built over an earlier church, the apse of which has only recently been discovered (Popkonstantinov et al., 2010, 2015). The relative chronology of the appearance of the two successive churches can be placed between the 4th and the late 6th century CE. There is no evidence of a permanent settlement on the island and it seems likely that a monastic community cared for the two Early Byzantine churches. The later basilica itself underwent three major periods of reconstruction until the first quarter of the 17th century (Dimova et al., 1990: 195). A second church in the complex provides an outstanding example of the triconch plan, its dome supported by pilasters built in the corners of the nave (Fig. 2B). The side bays of the narthex terminated to the east into brick-vaulted semicircular niches and apparently functioned as chapels. The sanctuary consisted of spacious presbyterium, prothesis and diakonikon intercommunicating with each other and with the nave. Fragments of wall paintings, marble cornices, window frames, and an altar screen provide evidence for the lavish interior decoration of the church. The walls of the nave and the narthex survived to a considerable height $(\sim 2-3 \mathrm{~m})$, perfectly demonstrating the building technique of alternating bands of stones and bricks with employment of wooden beams in the core of the walls. On the basis of the peculiarities of the masonry and the exterior decoration, the construction of the church is dated to the late 13th/early 14th century CE, with little doubt that it served as the katholikon of the monastery of St John the Forerunner which is thought to have been built by Michael Glabas Tarchaniotes, a Byzantine high military commander, in the restored monastery in the late 13th century (Dimova, 2008). 


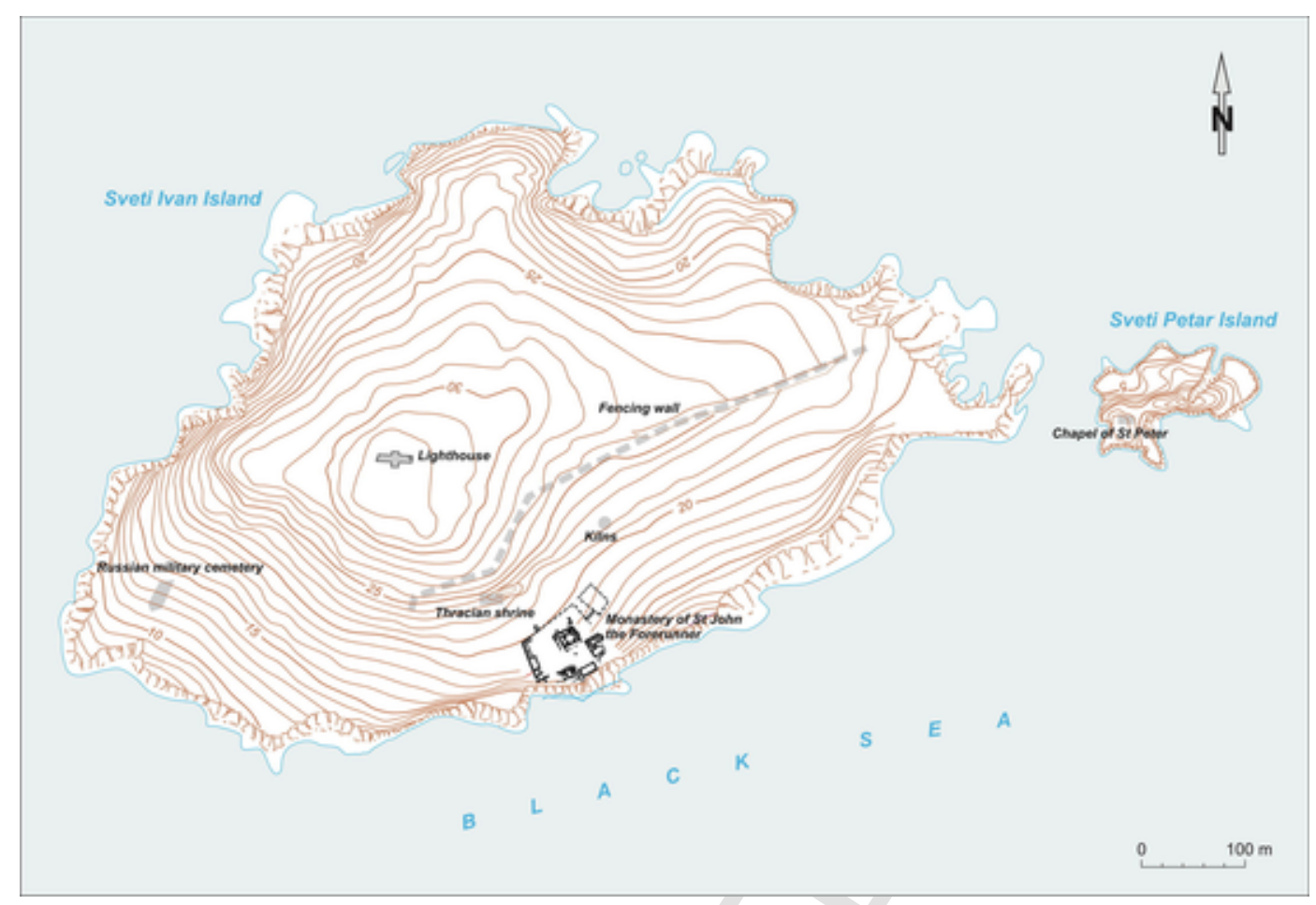

Fig. 1. Map of Sveti Ivan, and the archaeology of the island.

\section{Literature related to the monastery}

Sveti Ivan is mentioned under the name of Sangioanne in a Catalonian portulan dating to the 14th century and Hagios Ioannes in 16th-century Greek copies of a Venetian portulan chart from the 15th century CE (Dellate, 1947, 1958). According to the Byzantine poet Manuel Philes, Michael Glabas Tarchaniotes in the course of his victorious raid along the coast between Agathopolis (modern Ahtopol) and Mesembria (modern Nessebur) in CE 1262, restored and adorned the "monastery of the Prodromos" on the island of "Nesion", after finding it in a wretched state with only six monks residing there (Miller, 1854).

With respect to later events related to the monastery that are recorded in the sources, however, it seems more plausible that the monastery was not restored during that raid but some thirty years later. More precisely, it might have taken place while the konostaulos Michael Glabas was present in Sozopol and the surrounding region, on the orders of the Emperor Andronikos II Palaiologos (1282-1328). According to George Pachymeres, at the time of Michael Glabas' visit, Kosmas, a native from Sozopolis, was living as a monk on "an island". It seems quite plausible that this was the island where "the monastery of the Prodromos" was situated, thus explaining the attention paid to its care by the Byzantine dignitary. Some time later, the same Kosmas, at the recommendation of Michael Glabas, became patriarch of Constantinople under the name of John XII Kosmas (1294-1303) (Pachymérès, 1984). After leaving the patriarchal see of Constantinople in CE 1303 he returned to Sozopolis and most likely retired to the island monastery of Sveti Ivan (Laurent, 1969). The monastery maintained and further expanded its possessions, throughout the 15th century and survived until CE 1629 when it was finally deserted under the pressure of the Ottoman Turks, having served as a refuge for Cossack pirates.

In addition to its well-documented history as an imperial and patriarchal monastery, St John the Forerunner on the island of Sveti Ivan became known for its library and scriptorium. To date, forty-five codices from the monastic library are known to have survived and forty out of these are kept in the library on the island of Chalke in the Sea of Marmara, where they were brought after CE 1629. The codices include liturgical books and writings of the Church fathers, all of them written in Greek. The earliest manuscripts dated between the 12th century and the middle of the 15th century were copied at various places as evident from the scribal notes, while the majority of the books dating from between the middle of the 15th century to the beginning of the 17th century were copied in the scriptorium of the monastery itself (Dimitrov, 1981).

Of the medieval monasteries along the west coast of the Black Sea, that of St John the Forerunner on the island of Sveti Ivan is not only one of the best documented generally, but also provides a rare case where the written evidence matches the archaeological evidence from the site itself.

\section{Archaeological evidence}

The main elements of the monastery revealed to date are the surrounding wall with the western and north gate, the cells along its western and north sections and a number of buildings to the south of the churches (trapeza, kitchen, a large baking oven, a representative building, and a deep cistern) (Fig. 2). All of them belonged to the last period of activity of the monastery, dating from the 15th to the first quarter of the 17th century. The last archaeological campaigns revealed the tomb of a young man in the western gallery of the triconch, perhaps one of the donors of the monastery, buried with his stirrup boots and a tiny glass bottle. In addition, two bronze punches, used to produce stamped decoration on the leather covers of codices, were found in one of the rooms along to north surrounding wall, implying the location of the monastic scriptorium (Popkonstantinov et al., 2015).

\section{The reliquaries}

During excavations in 2010, a sealed marble reliquary was found inside a tiled cavity beneath the pillar supporting the high altar of Basilica A2. Petrographic analysis indicated this is made of white pure granoblastic marble with uniformly sized equidimensional grain structure ('sugar marble'). With its gabled lid, adorned with four small acroteria at the corners, the object is part of a class of approximately 200 surviving Byzantine reliquaries that imitate the form and fabric of the sarcophagi produced for export in the quarries of Asia Minor and the Aegean region between the 2nd to 4th c. AD (Kazan, 2015: 84). Furthermore, given its highly polished surface, fine white marble and central, elliptical recess in its lid, it forms part of an elite type of sarcophagus reliquaries. Of these, approximately 20 examples survive, all found within $400 \mathrm{~km}$ of the Byzantine capital, Constantinople, where it has 


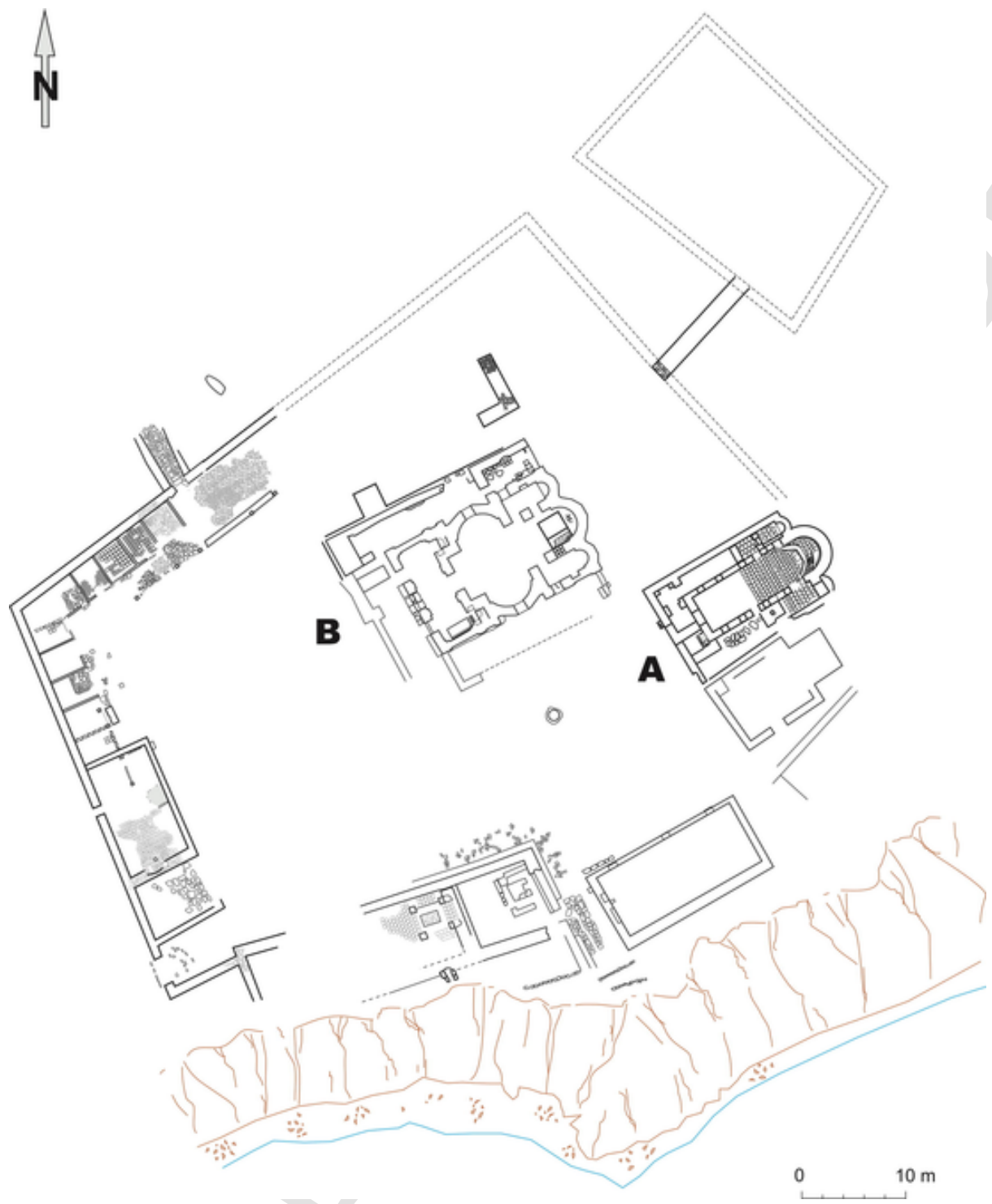

Fig. 2. Plan of the churches and monastic complex on Sveti Ivan. A: the early church comprising a tri-aisle basilica with a single-apse sanctuary. B: the second church, a triconch with dome.

-112). On the basis of its shape, the reliquary can be dated to the 5th-6th century (Fig. 3) (Popkonstantinov et al., 2010).

Further excavations revealed that this reliquary was moved to its final position from the sanctuary of the earlier church: remains of its apse were found en- closed within the floor and side walls of the sanctuary of the basilica. On the spot of the pillar supporting the altar table of the earliest church a small stone container was also excavated in 2010. A Greek inscription running across the surfaces of this mentions the name of a certain Thomas, asking for the Lord'

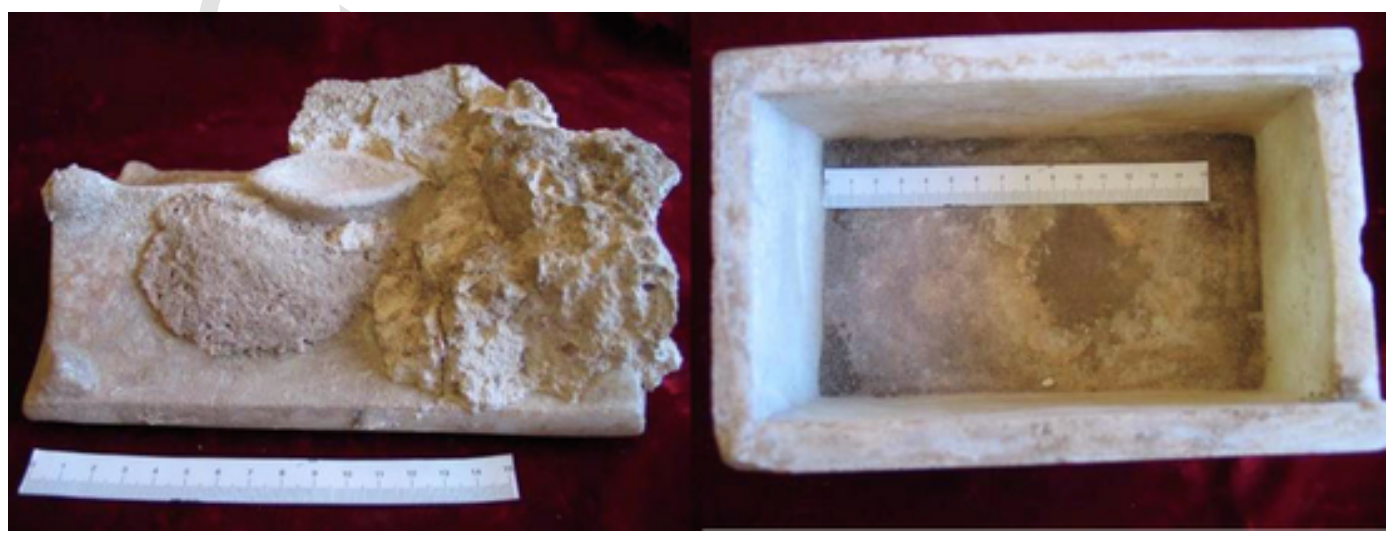

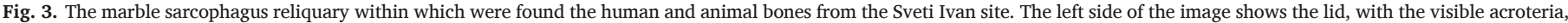
the right side is the marble box over which the lid slides into place. 
s protection, mentioning the name of St John, and the date of June 24th (Fig. 4). Both the date noted, which is the feast of the Nativity of St John the Baptist - the patron saint of the monastery documented in the 13th century - raise the possibility that at some point, not later than the 6th century as suggested by the palaeographic features of the inscription on the stone container, the latter was used to transport relics of St John the Baptist to the island. There they may have been moved to the marble reliquary, which was finally placed beneath the altar table of the earliest church. After the destruction of the latter, the marble reliquary was transferred beneath the altar table of the new basilica which was constructed over the previous one (Popkonstantinov et al., 2010, 2015).

We undertook a petrographic analysis of this smaller stone reliquary. An Amplival-pol-u polarised light microscope was used to study two thin section samples, with microphotographs taken by using universal microscope Leica DM 2500P. All analyses were undertaken at the University of Mining and Geology, Sofia, Bulgaria. The container was analysed in order to establish the provenance of the raw material used in its manufacture. Initial stereomicroscopic observations show that the rock sample has a white colour with light brown nuances, it is rather friable, fine-grained and contains some calcite, attested by its low response to diluted $\mathrm{HCl}$. It contains crystaloclasts of quartz, feldspars, biotite and vitroclastic/volcanic glass material.

The use of polarised light microscopy suggests that the main rock component is based on 0.2 to $0.3 \mathrm{~mm}$ ridged rhyolite vitroclastic material with porous and fluidal structure (pumice). The glass is zeolitised. The vitroclastic components are embedded into smectite (montmorillonite) resulting from the change of the zeoliths, the latter caused by (underwater) weathering. The crystalloclasts reach up to $20 \%$ and are present by angular quartz, sanidine with characteristic cleavage, and rarely - acidic plagioclase feldspars and biotite. The magnetite is powdery. The presence of microaggregates of powdery calcite indicates that the sedimentation of the volcanoclastic materials happened in a marine environment. The structure of the rock is crystallovitroclastic. The rock type may be defined as a rhyolitic tuff. It shows an advanced phase of zeolithisation and a partial transformation into smectite, which has clearly differentiated adsorption properties. This may explain the well preserved nature of the objects kept in this smaller reliquary. At the same time, the processes mentioned above resulted in the porosity of the rock and its low compactness.

The pumiceous, vitroclastic appearance of the material, and especially its fluid structure, show similarities with rocks from the Urgup formation of Cappadocia, formed in the Middle Miocene-Early Pliocene (13-4 million years). Recent geological studies undertaken by Turkish colleagues have demonstrated that this formation consists of rhyolite tuffs and ignimbrites reaching a remark-

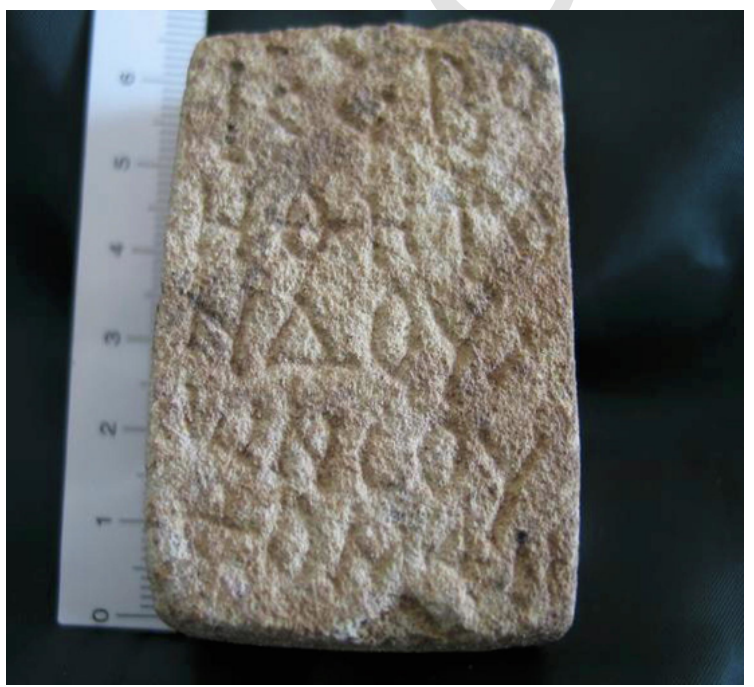

Fig. 4. Detail of the Greek inscriptions on the second tuff box found underneath the altar in the old church on Sveti Ivan. The inscription says "KY [PIE] BO $\eta \Theta \eta$ TON $\Delta$ OY $\Lambda$ ON COY $\Theta \mathrm{O} \mu \mathrm{A}$ " ("Lord, help your servant Thomas"). The inscription continues on the outer part of the box: " $\Theta$ (indecipherable) $\quad \mathrm{NnA}$ TOY $\mathrm{A} \Gamma \mathrm{nOY}$ nOANOY unNn nOYNnOY KA able thickness. Cappadocian subterranean towns have been constructed within the rock. The ignimbrite is a volcanogenic-clastic rock that has properties of lava and pyroclastic flow deposits. It consists of small particles of volcanic glass, pumice, fluidal vitroclastic materials and crystalloclasts. The tuffs have analogous composition but were deposited in an aquatic environment, whereas the ignimbrites are formed mainly by deposition of pyroclastic elements on the mainland - the latter resulting in their thick and solid appearance.

There are, then, strong parallels between the Cappadocian rhyolite tuffs and the reliquary which suggest that reliquary may have been made of this material.

\section{The relics}

Nine pieces of bone, six human and three animal, were found in the marble reliquary. According to the osteological analyses carried out by J. Jordanov, the pieces of human bones can be identified as:

1. Right maxillary bicuspid tooth (premolar).

2. Right fragment of a maxilla.

3. A fragment of a right rib.

4. A proximal fragment of the second or third metacarpal.

5. A fragment of a tubular bone, most probably a radius.

6. A small fragment most probably from a tibia or a femur.

In addition, three animal bones were also found; one of Bos sp. and two of Ovis/Capra.

\section{Methods}

\subsection{Radiocarbon dating}

Radiocarbon dating of samples from the excavations on Sveti Ivan was undertaken at the Oxford Radiocarbon Accelerator Unit (ORAU) at the University of Oxford. Samples of bone were drilled in Sozopol using an NSK drill fitted with tungsten carbide drill bits. Pre-treatment of the bones was carried after Brock et al. (2010). Coarsely ground bone powder was loaded into a glass $10 \mathrm{~mL}$ test tube. A sequence of $0.5 \mathrm{M}$ $\mathrm{HCl}, 0.1 \mathrm{M} \mathrm{NaOH}$ and $0.5 \mathrm{M} \mathrm{HCl}$ was used to treat the bone, interspersed with rinsing with ultra-pure (MilliQ⿱一𫝀) ${ }^{\mathrm{TM}}$ ) water between each reagent. Crude collagen was gelatinised in pH3 solution at $75{ }^{\circ} \mathrm{C}$ for $20 \mathrm{~h}$. The gelatin solution was filtered using a polyethylene Eezi-filter ${ }^{\mathrm{TM}}$ whose pore size ranges between 45 and $90 \mu \mathrm{m}$, that is precleaned by thorough rinsing and ultrasonication and the insoluble residues discarded. The filtered gelatin was then pipetted into a pre-cleaned ultra-filter (Vivaspin ${ }^{\mathrm{TM}} 1530 \mathrm{kD}$ MWCO) and centrifuged at 2500-3000 rpm until $0.5-1 \mathrm{~mL}$ of the $>30 \mathrm{kD}$ gelatin fraction remains (typically $20-40 \mathrm{~min}$ ) (for the human bone this was not applied due to the low sample size of the recovered collagen). This gelatin was freeze-dried ready for combustion in a CHN analyser.

Ultrafiltration based on the method originally described by Brown et al. (1988) has been utilized since 2000 at the ORAU. The precleaning of the ultrafilters is carried out using the methods outlined by Brock et al. (2007). Combusted gelatin samples were analysed using a Europa Scientific ANCA-MS system consisting of a 20-20 IR mass spectrometer interfaced to a Roboprep CHN sample converter unit operating in continuous flow mode using a He carrier gas. This enables the stepwise measurement of $\delta^{15} \mathrm{~N}$ and $\delta^{13} \mathrm{C}$, nitrogen and carbon content and calculation of $\mathrm{C}: \mathrm{N}$ atomic ratios. $\delta^{13} \mathrm{C}$ values for radiocarbon measurements cited in this chapter are reported with reference to VPDB. Graphitisation of the sample $\mathrm{CO}_{2}$ was undertaken over an iron catalyst in an excess $\mathrm{H}_{2}$ atmosphere at $560{ }^{\circ} \mathrm{C}$ prior to AMS radiocarbon measurement.

\subsection{Ancient DNA analysis}

We sampled three of the human relics for ancient DNA analysis: 1) the metacarpal bone (that was also used for radiocarbon dating), 2) a small rib fragment, and 3) a tooth. However, due to the precious nature of the relics we had to sample the remains in the Church 
ing a cordless drill fitted with tungsten carbide drill bits, wearing facemasks, protective clothing, and disposable gloves to minimise contamination risks. All subsequent steps, including DNA extraction and library preparation were carried out in the dedicated ancient DNA facilities at the Center for GeoGenetics in Copenhagen, Denmark.

DNA was extracted using a silica-based method (Rohland and Hofreiter, 2007) and eluted into $60 \mu \mathrm{l} \mathrm{EB}$ buffer. Following DNA extraction, $30 \mu \mathrm{l}$ of each extract was built into DNA libraries using the NEBNext ${ }^{\circledR}$ DNA Sample Prep Master Mix Set 2 and Illumina specific adapters (Meyer and Kircher, 2010). The DNA libraries were then amplified and indexed in $50 \mu \mathrm{l}$ PCR reactions using sample-specific barcodes. The optimal number of PCR cycles was determined by qPCR. The amplified libraries were purified using AMPure XP beads (Beckman Coulter), quantified on a 2200 TapeStation (Agilent Technologies), pooled in equimolar amounts, and sequenced on an Illumina HiSeq 2500 run in SR mode. Basecalling was done with CASAVA-1.8.2 and only reads with correct indexes were kept.

The raw sequencing data (FASTQ files) were then processed using the Paleomix pipeline (Schubert et al., 2014). Adapter sequences and low quality stretches of DNA at the ends of reads were removed using AdapterRemoval (Schubert et al., 2016). Reads below 25 nucleotides were also removed. Trimmed and filtered reads were mapped to the human reference genome (build 37.1) using bwa v.0.7.5 (Li and Durbin, 2009), with the seed disabled to allow for better sensitivity (Schubert et al., 2012). The mitochondrial genome sequence was replaced with revised Cambridge reference sequence (rCRS) (Andrews et al., 1999). The minimum mapping quality was set to 25 . Clonal reads were removed using samtools' rmdup function (Li et al., 2009) and ambiguously mapped reads were removed by controlling for XT and XA tags.

\section{Results}

\subsection{Radiocarbon dates}

We obtained three radiocarbon dates from the animal bones in the marble reliquary:

OxA-24886 JTB1a, bone, Capra/Ovis $\delta^{13} \mathrm{C}=-18.92420 \pm 27 \mathrm{BP}$

OxA-24887 JTB2a, bone, Bos taurus $\delta^{13} \mathrm{C}=-17.12476 \pm 28$ BP

OxA-24888 JTB3a, bone, Capra/Ovis $\delta^{13} \mathrm{C}=-19.12443 \pm 28 \mathrm{BP}$

These are conventional radiocarbon ages, and must be calibrated in order to be properly interpreted. When this is done using the Reimer et al. (2013) INTCAL13 calibration curve, they calibrate to the period $800-400$ BCE. It is possible that these bones were obtained from an Iron Age context and placed into the reliquary to make the bone collection more impressive in terms of size (although see below for an alternative explanation).

For the human materials, we attempted sample pretreatment on two bones. The ulna and premolar tooth were too small to properly date so these were not attempted. The bone from the rib failed to give any collagen, so we were unable to obtain a date. We were, however, able to extract collagen from the metacarpal, but it was at a very low level due to the small size of the bone that was originally sampled $(190 \mathrm{mg})$. The sample collagen was not ultrafiltered due to its small size, but was taken through the gelatinization and filtration steps. The chemistry was acceptable, with the exception of the $\mathrm{C}: \mathrm{N}$ ratio which was higher than usually accepted (2.9-3.5), although we think this is due to the small size of the combusted sample compared with the standards run in the same combustion run, rather than the collagen being problematic in terms of contamination.

The conventional radiocarbon determination was $1958 \pm 30$ BP (OxA-X-2430-47). In Table 1 the chemical and analytical data from all of the samples dated is shown. The sample has an 'OxA-X' prefix to denote the fact that the bone was low in collagen. The sample chemistry for all of the dated specimens is shown in Table 1 .

The carbon and nitrogen stable isotope values are interesting with a $\delta^{13} \mathrm{C}$ of $-17.8 \%$ and a $\delta^{15} \mathrm{~N}$ of $9.9 \%$, these suggest a diet that may have either a small component of fish in the diet or perhaps some protein influenced by a C4 plant-based food source. It is difficult to determine which, although the $\delta^{15} \mathrm{~N}$
Table 1

Analytical chemistry results associated with the bones from Sveti Ivan ${ }^{1}$.

\begin{tabular}{lllllllll}
\hline OxA & Species & $\begin{array}{l}\text { Wgt } \\
(\mathrm{mg})\end{array}$ & $\begin{array}{l}\text { Yld } \\
(\mathrm{mg})\end{array}$ & $\begin{array}{l}\text { Yld } \\
(\%)\end{array}$ & $\% \mathrm{C}$ & $\begin{array}{l}{ }^{13} \mathrm{C} \\
(\% \circ)\end{array}$ & $\begin{array}{l}\delta{ }^{15} \mathrm{~N} \\
(\% \circ)\end{array}$ & C:N \\
\hline $2430-47$ & H. sapiens & 190 & 2.3 & 1.2 & 43.7 & -17.8 & 9.9 & 3.6 \\
24886 & Capra/Ovis & 300 & 22.9 & 7.6 & 43.6 & -18.9 & 5.1 & 3.1 \\
24887 & Bos taurus & 650 & 40.5 & 6.2 & 46.1 & -17.1 & 6.3 & 3.1 \\
24888 & Capra/Ovis & 480 & 38.4 & 8 & 44.9 & -19.1 & 8.1 & 3.2
\end{tabular}

1 Radiocarbon ages are conventional ages in years BP after Stuiver and Polach (1977). Stable isotope ratios are expressed in \%o relative to vPDB and nitrogen to AIR. Mass spectrometric precision is $\pm 0.2 \%$ for carbon and $\pm 0.3 \%$ for nitrogen. Wgt denotes the amount of bone pretreated. Yld represents the weight of collagen in milligrams. $\%$ Yld is the percent yield of extracted collagen as a function of the starting weight of the bone analysed. \%C is the carbon present in the combusted collagen. C: $\mathrm{N}$ is the atomic ratio of carbon to nitrogen. This should range between 2.9 and 3.5 but can be affected by low mass of the sample to standard ratio during combustion. This accounts for the slightly higher value on OxA-X-2430-47.

value appears not to be greatly influenced by increasing trophic level effects often seen in marine and freshwater carbon food webs. More information would be required from contemporary plant and animals for a more confident dietary attribution and these will not be forthcoming. The calibration of the result is shown in Fig. 5. The result fits within the 1 st century $\mathrm{CE}$. At $90.6 \%$ prob. the age range is $40 \mathrm{BC}-89 \mathrm{cal} \mathrm{AD}$ and at $68.2 \%$ the result is $5-75 \mathrm{cal} \mathrm{AD}$.

\subsection{Ancient DNA results}

We generated around 10 million reads per sample of which between 0 and $1.7 \%$ could be uniquely mapped to the human reference genome (hg19). For two of the samples, we also recovered mitochondrial DNA reads (see Table 2), covering $32 \%$ and $48 \%$ of the mtDNA genome, respectively. Analysis of the mtDNA reads revealed the same mtDNA haplogroup: J/J1. However, fur-

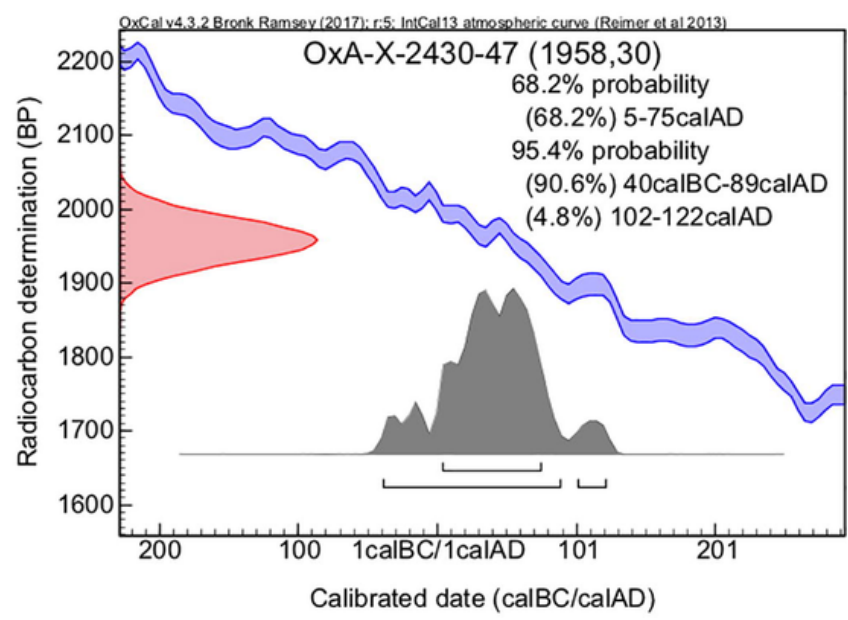

Fig. 5. Calibration of the radiocarbon date from the metacarpal bone. Calibrated using INTCAL13 (Reimer et al., 2013) and OxCal 4.2 (Bronk Ramsey, 2009).

Table 2

Mitochondrial DNA sequences recovered from three of the human relics from Sveti Ivan.

\begin{tabular}{llllll}
\hline Sample \# & $\begin{array}{l}\text { mtDNA } \\
\text { reads }\end{array}$ & $\begin{array}{l}\text { Average read } \\
\text { length }\end{array}$ & $\begin{array}{l}\text { mtDNA } \\
\text { coverage }\end{array}$ & $\begin{array}{l}\text { mtDNA } \\
\text { hg }\end{array}$ & $\begin{array}{l}5^{\prime} \mathrm{C} \\
\text { to T }\end{array}$ \\
\hline $\begin{array}{l}\text { 1, } \\
\text { premolar }\end{array}$ & 205 & $72.8 \mathrm{bp}$ & $48 \%$ & $\mathrm{~J} 1$ & 0.0 \\
$\begin{array}{l}3, \text { rib } \\
4,\end{array}$ & 0 & $\mathrm{n} / \mathrm{a}$ & 0 & $\mathrm{n} / \mathrm{a}$ & $\mathrm{n} / \mathrm{a}$ \\
metacarpal & 101 & $72.7 \mathrm{bp}$ & $32 \%$ & $\mathrm{~J}$ & 0.0 \\
\hline
\end{tabular}


ther analysis of the DNA fragments using MapDamage (Jónsson et al., 2013) revealed that the sequences lacked the post-mortem damage patterns that are characteristic for ancient DNA (i.e. apparent $C$ to $\mathrm{T}$ substitutions towards the $5^{\prime}$-ends of DNA molecules; see Fig. 6), indicating that the sequences are not ancient, but likely modern contamination. We therefore did not analyse those data further.

\section{Discussion}

The radiocarbon determination suggests that one of the remains excavated on Sveti Ivan comes from an individual that lived in the 1st century CE. Unfortunately, the ancient DNA analyses were inconclusive, therefore it is impossible for us to link the human remains together and explore any relationship status between them. They could belong to several different individuals or just to one; we cannot resolve this using the current data.

The historical record concerning the relics of John the Baptist interestingly provides some evidence for links with the Black Sea. With the obvious exception of the Gospel texts there is no evidence concerning the question of the physical remains of John the Baptist until the end of the 4th century CE, when the tomb of John the Baptist is recorded alongside that of the biblical prophet Elisha, at a place called Sebaste in Palestine. This was in the possession of a community of monks and nuns, established presumably between ca. 330 (Constantine ended the persecution of Christians in the region in 324 and the Bordeaux Pilgrim's account of 333 mentions no monastic settlement) and 361-362, when the site was attacked by pagans (see Theodoret in Scheidweiler (1991)). St John's bones, along with those of the Prophet Elisha (fl. 9th c. BC), were burned, mingled with those of animals and scattered (see Philostorgius, Historia Ecclesiastica, in Bidez and Winkelmann, 1981). It was not uncommon for desecration of this type to include the mixing of relics with animal bones, in order to confuse and discourage attempts to recuperate them for veneration (Dindorff, 1832). However, the early date of the animal bones found in the marble reliquary may indicate rather that the relics had been buried at a site that had been settled several hundred years previously. This would support the written sources description of St John's burial at Sebaste, a site settled since Biblical times. Monks from Jerusalem mingled with those desecrating the remains and collected as many of St John's relics as possible, and brought them to Philip, founder of their monastery (see Rufinus of Aquileia, Historia Ecclesiastica). Philip, in turn, sent some of the relics to the Patriarch, Athanasius, Bishop of Alexandria (328-373), and, it appears, to the Metropolitan Bishop of Palestine, Acacius of Caesarea. According to the same source, the relics in Alexandria were "closed up within a hollowed-out place in the sacristy wall [...], preserving them for the benefit of the next generation". A 7th century account records these were discovered a generation later during the era of Patriarch Theophilus (385-412), who constructed a purpose-built church in Alexandria in 395 (see John of Nikiu, trans. by Charles, 1916). This source indicates that these relics, originally from John's tomb in Palestine, included parts of the saint's head, which presumably would therefore have been found in the tomb with his body. Meanwhile, in the reign of the emperor Valens (364 to 378), it became known at court that a relic of John the Baptist's head had been discov- ered by monks living in Jerusalem, who had later moved to Cilicia, in southern Anatolia (Bidez and Hansen, 1995). This region bordered Cappadocia, a suggested source for the tuff reliquary found at Sveti Ivan, which may therefore support the account of the relics' passage from Jerusalem to Anatolia. Valens commanded that the relic be brought to Constantinople. The monastic community attending the relics appears to have migrated with it. These monks adhered to the teachings of Macedonius, bishop of Constantinople, and it would therefore appear that they found the relic at a point between his accession in 342 and 378, the death of Valens. Given the absence of any other traditions relating to relics of St John the Baptist at this time, it therefore seems plausible that these monks were from the same monastery of Philip in Jerusalem that had received the relics from the desecrated tomb of the Baptist at Sebaste in 361-2.

In 391, the emperor Theodosius came to Cosilaos and removed the relic of the Baptist's head to Constantinople. He enclosed it in a small casket or urn, wrapped it in a cloak of imperial purple and moved it to the Hebdomon, just outside Constantinople, where he built a magnificent church to hold it (Bidez and Hansen, 1995). The words used to describe this apparently portable casket ( $\theta \dot{\eta} \kappa \eta$ and $\sigma 0 \rho \sigma_{\varsigma}$ ) are used by the same author to describe a sarcophagus reliquary sealed in a crypt below a church in Constantinople at around the same time (Sozomen, Historia Ecclesiastica). In 394, Theodosius reunified the Empire at the Battle of the Frigidus, having prayed over John's relics before the battle that the Baptist might fight on his side (Bidez and Hansen, 1995). Following this victory, it seems, relics of the Baptist appeared in northern Italy. Gaudentius, Bishop of Brescia (387-410), was able to present relics of St. John the Baptist at the dedication of his basilica, the Concilium Sanctorum, along with others of St Luke the Evangelist and the apostles St Thomas and St. Andrew (Glück and Polaschek, 1936). Relics of all these saints were at the time present together only at Constantinople. Victricius, bishop of Rouen in northern Gaul (393-417), also received relics of Sts. John the Baptist, Andrew, Luke and Thomas, along with others of St Euphemia, a martyr from Chalcedon, her shrine facing Constantinople across the Bosphorus (Victricius of Rouen in Mulders and Demeulenaere, 1985). One might assume that such reliquaries were secondary items such as oil or cloth wrappings sanctified by contact, but the reliquary of Daedalia, found in what was Ambrose's Basilica Apostolorum in Milan, shows that this was by no means always the case. It is possible that the bone fragments this contained were those of Sts. Andrew, Luke and Thomas, said to have entered the possession of the Basilica Apostolorum after its dedication in ca. 386. Their arrival is recorded in the Martyrologium Hieronymianum for May 9, while another entry in the Martyrologium concerning Milan, for November 27, commemorates a deposition of relics of St. John, St. Andrew, St. Luke and St. Euphemia of Chalcedon (McLynn, 1994). All of these relics arrived in the West at around the time when Theodosius I acquired the relic of St John the Baptist's head. However, neither the sources nor the description of the bones in the Daedalia reliquary specify that these relics came from a head. It has been suggested that Theodosius I could have brought these relics in his train when he visited the city in 388-391, or towards the time of his death in Milan in 395 (McLynn, 1994). Most appear in the collections of bishops, who obtained them along with relics of St An- a

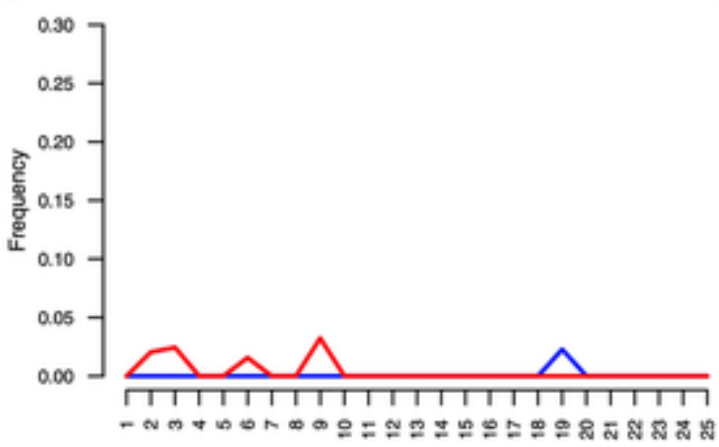

b

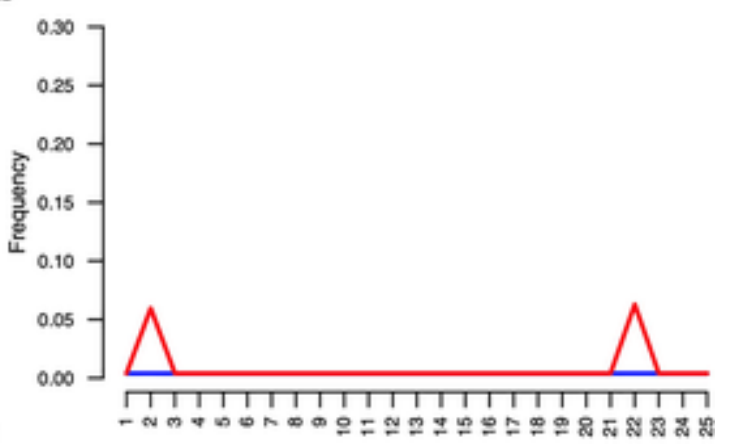


drew and St Luke. The remains of both those saints were by that time kept in the Holy Apostles Church at Constantinople, an imperial foundation and the place where the city's emperors were buried. In view of this fact, and that relics of the Baptist were kept in another imperial foundation, the church at the Hebdomon, it seems likely that relics from these shrines were distributed through the agency of the imperial government. One can observes a tight clustering of these relic donations around Milan, an imperial capital alongside Constantinople until 402, and part of the same united empire until Theodosius I's death in 395. This pattern is even more pronounced if one adds the ancient churches dedicated to St John the Baptist in which Byzantine reliquaries from our period have been discovered: those at Castello Brivio and Mariano Comense, the latter a sarcophagus reliquary containing not only bone but remains of purple fabric, an imperial product in this period (Baserga, 1904; Grabar, 1958; SenaChiesa, 1991). It therefore seems evident that unspecified bone fragments attributed to John the Baptist were circulating amongst the Byzantine imperial elite soon after Theodosius I is said to have removed a relic of the Baptist's head to Constantinople in c.391.

In Constantinople, a number of churches dedicated to the Baptist also sprang up in these early years, most connected with Syrian monastic communities (Janin, 1969), who saw St John as a model ascetic. These provide a relevant context for the foundation of the monastery on Sveti Ivan. The earliest monastery in the capital, that of Dalmatos, founded by the Syrian monk Isaac in 382, is said to have included a church to John the Baptist by the 5th-6th c. (Janin, 1969). Between 395 and 408, a church of St John the Baptist is said to have been built in the Arcadianae, the estate of the emperor Arcardius, north-east of Hagia Sophia (Janin, 1969). By 400, what later became known as the Monastery of John the Baptist was developing near the saint's martyrium at the Hebdomon (built in 392), as individual ascetics established themselves there (Janin, 1969: 267). It is well known that the diocesan province of Thrace, with its seat at Constantinople and extending up the Black Sea coast of modern Bulgaria, was home to numerous monasteries and to a significant Syrian presence including monks and merchants (Minchev, 2003: 17-18; Georgiev, 2006), hinting at a possible Syrian connection with the monastery of St John on the island of Sveti Ivan. While Constantinople's imperial authorities were the major source of relics attributed to the Baptist in this period, it remains nevertheless possible that such relics may also have been acquired from the eastern Mediterranean (e.g. the Holy Land or Egypt). Further scientific analysis of the relics, their reliquaries, and of the site itself may help provide a definitive answer.

\section{Conclusions}

The results described in this paper provide scientific results for a corpus of bone excavated beneath a 4th-5th century CE church in Bulgaria on the island of Sveti Ivan. The results do not disprove the notion, proposed by excavators, that the monks who acquired the remains believed them to be those of John the Baptist, although we are at pains to suggest that scientific results are only able to ever show the opposite, not to confirm a positive identity. Problems arose due to contaminating DNA in the samples we analysed which meant that it was not possible to produce reliable genetic reads from the bones. To explore the issue of the relatedness of the human remains further, it would be necessary to re-sample in more controlled and contaminant-free conditions. It might be possible thereafter to test other relics housed in churches and museums elsewhere to compare the DNA and radiocarbon age information against other purported examples. The historic record provides an interesting trail that at least points to the possibility of actual relics moving in the direction of the Black Sea. Further work may shed light on whether this is of wider significance.

\section{Uncited references}

Bell and Mundell Mango (1982), Briggs et al. (2009), Canivet et al. (1977), Ginolhac et al. (2011), Kloss-Brandstätter et al. (2011), Krause et al. (2010), Maricic et al. (2011), Migne, 1844-1865, van Oven and Kayser (2009), Yang et al. (1999).

\section{Acknowledgements}

We thank the staff at the Oxford Radiocarbon Accelerator Unit (ORAU), University of Oxford, the Danish National High throughput Sequencing Center at the University of Copenhagen for technical assistance and the entire excavation team at the Sveti Ivan site for their efforts. We are grateful to Dr. Tanya Dzhanfezova (University of Veliko Tarnovo) for translation of the petrographic report. We are grateful to Professor Jordanov, Corresponding Member of the Bulgarian Academy of Sciences, for his work on the physical anthropology of the relics. This work was partially funded by the National Geographic Society Expeditions Council, for which we are grateful.

\section{References}

Baserga, G., 1904. Antiche capselle liturgiche in Brianza. Rivista Archeologica della Provincia e antica Diocesi di Como 100-120.

Bell, G., Mundell Mango, M., 1982. The churches and monasteries of the Tur 'Abdin, with introduction and notes by M. Mundell Mango, London.

Bidez, J., Hansen, G., 1995. Sozomen, Historia Ecclesiastica, VII.21. Sozomenus: Kirchengeschichte. GCS 4, Berlin.

Bidez, J., Winkelmann, F. (Eds.), 1981. Philostorgius: Kirchengeschichte. Mitdem Leben des Lucian von Antiochien und den Fragmenteneinesarianischen Historiographen. GCS 24 Philostorgius, Historia Ecclesiastica, VII.4.

Briggs, A., et al., 2009. Targeted retrieval and analysis of five Neandertal mtDNA genomes. Science 325, 318-321.

Brock, F., Bronk Ramsey, C., Higham, T.F.G., 2007. Quality assurance of ultrafiltered bone dating. Radiocarbon 49 (2), 187-192.

Brock, F., Higham, T.F.G., Ditchfield, P., Bronk Ramsey, C., 2010. Current pretreatment methods for AMS radiocarbon dating at the Oxford Radiocarbon Accelerator Unit (ORAU). Radiocarbon 52 (1), 103-112.

Bronk Ramsey, C., 2009. Bayesian analysis of radiocarbon dates. Radiocarbon 51, 337-360.

Brown, T.A., Nelson, D.E., Vogel, J.S., Southon, J.R., 1988. Improved collagen extraction by modified Longin method. Radiocarbon 30, 171-177.

Canivet, P., Leroy-Molinghen, A. (Eds.), 1977-9. The Life of James of Cyrrhestica, in Theodoret, Historia Religiosa XXI (Histoire des moines de Syrie: Histoire Philothée. SC 234, 257. 2 Vols. (1977-9).

Charles, R.H., 1916. The Chronicle of John (c. 690 A.D.) Coptic bishop of Nikiu : being a history of Egypt before and during the Arab conquest. London.

Dellate, A., 1947. Les portulans grecs. Liege-Paris, 231.

Dellate, A., 1958. II. Compléments. Brussels, 1958, 46-47.

Dimitrov, B., 1981. 'I monasteri di Sozopol nei secoli XIII-XV. Byzantino bulgarica (Sofia) 7 (1981), 279-281.

Dimova, V., 2008. Tsărkvite v Bălgarijaprez XIII-XIV vek [The churches in Bulgaria in the 13th -14th c.]. Sofia, 341-343.

Dimova, V. et al., 1990. Razkopki v manastira "Sv. Ivan Predteča" v Sozopol [Excavations of the monastery of St John the Forerunner in Sozopol]. In: Arheologičeski otkritija i razkopki za 1989 godina. Sofia, 1990, 194.

Dindorff, L. (Ed.), 1832. Chronicon Paschale, A.D. 362 (Chronicon Paschale, Vol.1., Corpus Scriptorum Historiae Byzantinae 16, (Bonn, 1832) p. 546).

Georgiev, 2006. Odessos - Theodoriada. A centre of monophysitism during the 6th century (the Dzhanavara Church and its Syro-Mesopotamian features). In: Minchev, A, Yotov, V. (Eds.), Early Christian Martyrs and Relics and Their Veneration in East and West Proceedings of the International Conference, Varna, November 20th-23th 2003, Varna, 291-308.

Ginolhac, A., et al., 2011. mapDamage: testing for damage patterns in ancient DNA sequences. Bioinformatics 27 (15), 2153-2155.

Glück, A., Polaschek, A. (Eds.), 1936. Gaudentius of Brescia, Tractatus, XVII, S. Gaudentiiepiscopi Brixiensis Tractatus. CSEL 68

Grabar, A., 1958. Ampoules de Terre Sainte, Paris.

Janin, R. 1969. La géographie ecclésiastique de l'empire byzantin. Volume III: Les églises et les monastères, second ed. Paris.

Kazan, G.C., 2015. Arks of constantinople, the New Jerusalem: the origins of the byzantine sarcophagus reliquary. Byzantion 85 (2015), 77-125.

Kloss-Brandstätter, A., Pacher, D., Schönherr, S., Weissensteiner, H., Binna, R., Specht, G., Kronenberg, F., 2011. HaploGrep: a fast and reliable algorithm for automatic classification of mitochondrial DNA haplogroups. Hum. Mutat. 32, 25-32 [http://haplogrep. uibk.ac.at/].

Krause, J., et al., 2010. A complete mtDNA genome of an early modern human from Kostenki, Russia. Current Biol. 20, 231-236.

Laurent, V., 1969. La chronologie des patriarches de Constantinople au XIII siècle (1208-1309). Revue des Études Byzantines 27, 147-148.

Li, H., Durbin, R., 2009. Fast and accurate short read alignment with Burrows- Wheeler transform. Bioinformatics 25, 1754-1760.

Li, H., Handsaker, B., Wysoker, A., Fennell, T., Ruan, J., Homer N., Marth, G., Abecasis, G., Durbin, R., 1000 Genome Project Data Processing Subgroup, 2009. The Sequence alignment/map (SAM) format and SAMtools. Bioinformatics 25, 2078-2079.

McLynn, N. 1994. Ambrose of Milan: church and court in a Christian capital (Berkeley), pp. 229-231.

Maricic, T., Whitten, M., Pääbo, S., 2011. Multiplexed DNA sequence capture of mitochondrial genomes using PCR products. PLoS ONE 5, e14004.

Meyer, M., Kircher, M., 2010, Illumina sequencing library preparation for highly multiplexed target capture and sequencing, Cold Spring Harbor Protocols 6, pdb.prot5448-pdb.prot5448.

Miller, E. (Ed), 1854. Manuelis Philae Carmina, vols. 1-2. Paris, 244. 
Mulders, I., Demeulenaere, R. (Eds.), 1985. De Laude Sanctorum, VI.35-6 (Victricii Rotomagensis de laude Sanctorum. CCSL 64, 69-93.

Migne, J.P. (Ed.), 1844-1865. Patrologia Cursus Completus, Series Latina. Paris.

Pachymérès, G., 1984. Relations historiques. Edition, introduction et notes par Al. Failler, traduction française par V. Laurent. I-II. (CFHB XXIV/1-2, Ser. Paris). Paris, 1984, VIII, $27-28$.

Popkonstantinov, K., Drazheva, Ts., Kostova, R., 2010. 'Srednovekoven manastir "Sv. Ioan Prodrom" na ostrov "Sv. Ivan", Sozopol [Medieval monastery "St John the Forerunner" on the island "Sv. Ivan", Sozopol], In: Arheologičeski otkritija i razkopki za 2009 godina. Sofia, 595-599.

Popkonstantinov, K., Drazheva, Ts., Kostova, R., 2015. 'Manastirat Sv. Ioan Prodrom na ostrov Sveti Ivan v svetlinata na novite arheologicheski prouchvaniya (2008-2013)' [Monastery "St John the Forerunner" on the island "Sv. Ivan" in light of new archaeological investigations], In: Izvestiya na Narodniya Muzej-Burgas V, 209-2017.

Reimer, P.J., Bard, E., Bayliss, A., Beck, J.W., Blackwell, P.G., Bronk Ramsey, C., Grootes, P.M., Guilderson, T.P., Haflidason, H., Hajdas, I., Hatté, C., Heaton, T.J., Hoffmann, D.L., Hogg
, A.G., Hughen, K.A., Kaiser, K.F., Kromer, B., Manning, S.W., Niu, M., Reimer, R.W., Richards, D.A., Scott, E.M., Southon, J.R., Staff, R.A., Turney, C.S.M., van der Plicht., J., 2013. IntCal13 and Marine13 Radiocarbon Age Calibration Curves 0-50,000 Years cal BP. Radiocarbon 55 (4), 1869-1887.

Rufinus of Aquileia, Historia Ecclesiastica, in PL XXI.461-540c.

Scheidweiler, F. (Ed.), 1991. Theodoret, Kirchengeschichte. GCS 44 (Berlin, 1954).

SenaChiesa, G. (Ed.), 1991. Milano capital dell'impero romano: 286-402 d.c. (Milan 1990), 301-304.

Soustal, P., 1991. Thrakien (Thrakē, Rodopē und Haimimontos). Tabula Imperii Byzantini 6. Vienna 285-286.

Stuiver, M., Polach, H.A., 1977. Discussion: Reporting of ${ }^{14} \mathrm{C}$ Data. Radiocarbon 19 , 355-363.

van Oven, M., Kayser, M., 2009. Updated comprehensive phylogenetic tree of global human mitochondrial DNA variation. Hum. Mutat. 30, E386-E394.

Yang, D., Eng, B., Waye, J.S., 1999. Improved DNA extraction from ancient bones using silica-based spin columns. Am. J. Phys. Anthropol. 105, 539-542. 